\title{
Interactive effects of juvenile defoliation, light conditions, and interspecific competition on growth and ectomycorrhizal colonization of Fagus sylvatica and Pinus sylvestris seedlings
}

\author{
Lidia K. Trocha ${ }^{1}$ - Ewa Weiser ${ }^{1}$ - Piotr Robakowski ${ }^{2}$ \\ Received: 3 November 2014 / Accepted: 14 May 2015 / Published online: 24 May 2015 \\ (C) The Author(s) 2015. This article is published with open access at Springerlink.com
}

\begin{abstract}
Seedlings of forest tree species are exposed to a number of abiotic (organ loss or damage, light shortage) and biotic (interspecific competition) stress factors, which may lead to an inhibition of growth and reproduction and, eventually, to plant death. Growth of the host and its mycorrhizal symbiont is often closely linked, and hence, host damage may negatively affect the symbiont. We designed a pot experiment to study the response of light-demanding Pinus sylvestris and shade-tolerant Fagus sylvatica seedlings to a set of abiotic and biotic stresses and subsequent effects on ectomycorrhizal (ECM) root tip colonization, seedling biomass, and leaf nitrogen content. The light regime had a more pronounced effect on ECM colonization than did juvenile damage. The interspecific competition resulted in higher ECM root tip abundance for Pinus, but this effect was insignificant in Fagus. Low light and interspecific competition resulted in lower seedling biomass compared to high light, and the effect of the latter was partially masked by high light. Leaf nitrogen responded differently in Fagus and Pinus when they grew in interspecific competition. Our results indicated that for both lightdemanding (Pinus) and shade-tolerant (Fagus) species, the light environment was a major factor affecting seedling growth and ECM root tip abundance. The light conditions favorable for the growth of seedlings may to some extent compensate for the harmful effects of juvenile organ loss or damage and interspecific competition.
\end{abstract}

Lidia K. Trocha

lidiatrocha@gazeta.pl

1 Institute of Dendrology, Polish Academy of Sciences, Parkowa 5, 62-035 Kórnik, Poland

2 Department of Forestry, Poznan University of Life Sciences, Wojska Polskiego 71E, 60-625 Poznań, Poland
Keywords Ectomycorrhiza $\cdot$ Light environment . Defoliation · Rootloss · Juvenile stage of growth · Sink-source relations $\cdot$ Nitrogen acquisition

\section{Introduction}

Seedlings of forest tree species are continuously exposed to a set of biotic (grazing, competition with other plants) and abiotic (water deficit, shading) stressors. A prolonged stress may be destructive for a plant when it overcomes plant tolerance. Repetitive plant damages may lead to unsuccessful reproduction and growth and, eventually, to plant death (Clark 1956; Myers 1981).

The effects of plant damages vary depending on the species, organ, and spatial distribution of damage within an individual plant (Maschinski and Whitham 1989). It remains poorly known whether plants may more easily overcome damages that are more distributed throughout the plant or concentrated in one organ (Avila-Sakar and Stephenson 2006). Additionally, plant age is a crucial factor influencing susceptibility to damages like grazing (McNaughton 1983; Muro et al. 1998). For seedlings growing under the tree canopy, the final level of damage also depends on the light conditions, e.g., animals may avoid seedlings growing in the shade (Lincoln and Mooney 1984).

Growth of the host and its mycorrhizal fungus symbiont is often closely linked, and hence, host damage may negatively affect the symbiont. The essential role of ectomycorrhizal fungal symbionts is reflected particularly in the supply of water (Davies et al. 1996; Shi et al. 2002) and nutrients (PerezMoreno and Read 2000; Lilleskov et al. 2002; Baxter and Dighton 2005), while the fungus requires photosynthates to maintain its functions (Hampp et al. 1999). Carbon flux from host foliage is crucial to maintain ectomycorrhizal fungi 
(EMF). From 1 to $21 \%$ of the net photosynthetic production is allocated to EMF (Hobbie 2006), and therefore, any aboveground damage may have an impact on root fate and EMF. The effects of damage of these organs may be important for ectomycorrhizal (ECM) morphotypes (both high carbon and low carbon demanding, Saravesi et al. 2008) and EMF species composition (Saikkonen et al. 1999; Kuikka et al. 2003) and, thus, plant maintenance and function. On the other hand, mycorrhizal species differ in their metabolic activities as shown for certain arbuscular mycorrhizal (AM) fungi (Lerat et al. 2003; Bever et al. 2009) and ECM fungi (Pena et al. 2010; Trocha et al. 2010). Thus, carbohydrate depletion may lead to a shift in composition of the mycorrhizal species toward less mutualistic species (Saravesi et al. 2008; Bever et al. 2009) as well as decline of sporocarp production as an effect of restriction of host resources to preserve ECM root tip colonization at an unchanged level (Kuikka et al. 2003). However, defoliation did not decrease the proportion of living ECM root tips (Saikkonen et al. 1999; Kuikka et al. 2003), suggesting a functional balance between carbon sources in plant foliage and belowground sink, i.e., roots and ectomycorrhizae (Saikkonen et al. 1999). In addition, defoliation may hinder whole root system development (Chapin and Slack 1979) due to transient declines in carbon allocation to fine roots (Kosola et al. 2001). Although several studies have examined the effect of carbon shortage on the fate of ECM root colonization (Saikkonen et al. 1999; Kuikka et al. 2003; Markkola et al. 2004; Saravesi et al. 2008), none have examined defoliation and/or root loss that occurs at a very young stage of seedling development. Young seedlings are more threatened by damage than saplings and older trees. Thus, their defoliation and root loss may cause high mortality and a decrease in tree species diversity.

Numerous studies have shown that a reduction of light leads to a decrease in plant biomass (e.g., Tester et al. 1986; Welander and Ottosson 1998). Bücking and Heyser (2003) demonstrated that in low light, Pinus sylvestris seedlings inoculated with the ECM fungus Suillus bovinus decreased P acquisition and $\mathrm{P}$ transfer to the host plant, confirming the role of carbohydrates in mycorrhizal function (Nehls et al. 2010). Shaded plants have lower root biomass compared to high-light conditions (Lambers et al. 1998). This observation suggests that in low-light conditions, plants allocate proportionally less carbon to the roots. Instead, those plants may invest more in leaf production to compensate for light shortage (Bloom et al. 1985 in: Bryla and Eissenstat 2005). However, this statement may be biased because of unequal size when plants are grown under different light conditions (Bryla and Eissenstat 2005). Also, plants experiencing defoliation or grazing on leaves can respond with an increase of photosynthesis in the remaining leaves (Oleksyn et al. 1998; Little et al. 2003).

Closely neighboring plants compete for soil resources. This rule is valid for both individuals of the same species (Facelli et al. 1999), different plant species, and plants with different nutrient needs (Pedersen et al. 1999; McHugh and Gehring 2006). Availability of mycorrhizal fungal inoculum strongly influences plant biomass under different plant densities. Studies performed mostly on arbuscular plants confirmed that individual plants performed best at the lowest plant densities and competed severely for nutrients when growing at higher densities (Koide 1991; Facelli et al. 1999). For example, Facelli et al. (1999) showed that Trifolium subterraneum plants had lower biomass when growing at higher densities; however, there was no significant effect of fungal inoculum on plant biomass at higher densities. Hartnett et al. (1993) showed that negative plant responses to arbuscular fungal colonization were noticeable for single plants or at low density, but were reduced in some cases at high plant density. This may be explained by a greater overlap of roots and successful competition and, hence, better acquisition of soil resources by larger nonmycorrhizal plants. Cheng and Bledsoe (2004) demonstrated that the grass Avena barbata growing at high density limited nitrogen availability for both co-occurring Quercus douglasii and soil microorganisms, suggesting a strong effect of interspecific competition and an advantage for the grass in nutrient acquisition. Archer and Detling (1984) observed that plants growing in competition responded with lower biomass and flowering, regardless of whether or not they were subjected to defoliation. This implies that the effects of competition might be more harmful for plant growth than aboveground injury. It is important to note that damaged plants could still compete efficiently with their neighbors for soil resources. Defoliation may hinder root development and in turn limit water and nutrient uptake (Evans 1972). However, defoliation does not always hinder nutrient acquisition, as shown by Chapin and Slack (1979).

We used tree species in our study that differ in their light requirements: shade-tolerant Fagus sylvatica (Minotta and Pinzauti 1996) and light-demanding P. sylvestris (Pearcy et al. 2004). The species respond differently to irradiance, with light-demanding $P$. sylvestris showing more pronounced changes in leaf morphology and thus better light exploitation than F. sylvatica (De Chantal et al. 2003). Shade-tolerant trees are better adapted to shade because they can survive light limitations in their juvenile period (Kitajima 1994).

This research was designed to study the responses of lightdemanding pioneer $P$. sylvestris and shade-tolerant $F$. sylvatica seedlings to interactive effects of partial foliage and/or root loss, light limitations, and interspecies competition on mycorrhizal root tip colonization, growth, and seedling mineral status. We tested the following hypotheses: (1) carbohydrate shortage under low-light conditions or damage treatments that simulate animal grazing will result in a decrease of growth, ECM root tip colonization, and leaf nitrogen content; (2) competition with grasses will decrease ECM root tip colonization, seedling growth, and leaf nitrogen content; (3) high-light 
conditions will reduce the destructive effects of both damage treatments (hypothesis 1) and competition (hypothesis 2); and (4) the above responses will be tree species dependent and Pinus seedlings will suffer more than Fagus seedlings under low light.

\section{Material and methods}

\section{Plant material}

Seeds of $F$. sylvatica and P. sylvestris were purchased from the Jarocin Forest District Seed Bank (Poland). The pine seeds were directly planted without any preliminary preparation, while beech seeds (in nuts) underwent cold stratification $\left(3{ }^{\circ} \mathrm{C}\right)$ for 10 weeks (i.e., until the appearance of the first germinated seeds). Seeds were screened for their mass and those of medium weights were planted into pots containing peat and perlite $(1: 1$, $v / v)$. Before planting into pots, seed germination was tested. Germinating seeds were treated with the fungicide Previcur 607 SL (Bayer) at $15 \%$ concentration. Young seedlings (just after cotyledon development) were carefully removed from the pots and subjected to leaf and root damage treatments simulating animal grazing (Table 1).

Seedlings of each treatment were then planted into larger pots $(5 \mathrm{~L})$. Soils were collected from monoculture $P$. sylvestris and $F$. sylvatica stands near Kórnik from the upper ca $20 \mathrm{~cm}$ after litter removal. Before seed planting, the soils were mixed together with peat $(1: 1: 1, v / v / v)$ and enriched by inorganic fertilizer $(3 \mathrm{~kg} / 1000 \mathrm{~L})$ (Osmocote Exact, Scotts).

Table 1 A set of juvenile damage treatments for Fagus sylvatica and Pinus sylvestris seedlings used in the experiment

\begin{tabular}{cl}
\hline Treatment no. & Description \\
\hline Fagus sylvatica & \\
1 & 1 cotyledon removed \\
2 & 1 cotyledon and $20 \%$ of the root by length removed \\
3 & $20 \%$ of the root by length removed \\
4 & Control (intact) \\
Pinus sylvestris & \\
1 & 1 cotyledon removed \\
2 & 1 cotyledon and $20 \%$ of the root by length removed \\
3 & 3 cotyledons removed \\
4 & 3 cotyledons and $20 \%$ of the root by length removed \\
5 & 5 cotyledons removed \\
6 & 5 cotyledons and $20 \%$ of the root by length removed \\
7 & $20 \%$ of the root by length removed \\
8 & Control (intact) \\
\hline
\end{tabular}

\section{Experimental design}

Seedlings were grown in shade tents made of polypropylene netting (Agrotex, Poland). On a cloudy day in April 2005, the photosynthetic photon flux density (PPFD) was simultaneously measured in the open and in a tent using linear photon detectors (Apologe Inc., USA). Then, for both shade treatments, the mean percent of full sunlight (relative photosynthetic photon flux density-rPPFD) was calculated. Two shade treatments were established: low light (5\% of full irradiance) and high light (50\%). These light regimes, low and high, used in the experiment, simulated the natural conditions of Fagus and Pinus seedlings grown under the dense forest canopy and openings, respectively.

In total, there were 60 pots randomly arranged in four blocks for each damage treatment under both light regimes. Three seedlings were grown in each pot. In the competition treatment, 20 transplanted grass individuals (Bromus sterilis L.) collected in early May in 2005 in the Kórnik Arboretum were used in each pot containing three seedlings of either F. sylvatica or $P$. sylvestris seedlings. For the competition experiment, we used 24 pots for each tree species, damage treatment, and light regime. After seeds of the grass developed (midsummer) and started germinating in the pots, the seedlings were carefully removed to maintain the fixed number of grass individuals.

\section{Ectomycorrhizal, morphological, and chemical characteristics of seedlings}

Fagus and Pinus seedlings were harvested monthly from July to November 2005. Eight seedlings of each damage treatment from both light conditions were used to determine whole plant as well as root, shoot, and leaf biomass; morphology of leaves and roots; and nitrogen, carbon, and carbohydrate contents of plants. Additionally, three to four seedlings from each treatment were used to assess ectomycorrhizal root tip abundance based on microscopic observations. Three to four seedlings growing in control or in competition with grasses per damage and light treatment were also collected in early September 2005 to quantify ectomycorrhizal colonization.

The extent of the ECM colonization was determined using a stereomicroscope. Ectomycorrhizal and nonmycorrhizal root tips were assessed, and the extent of the ECM colonization was expressed as a percentage of ECM root tips among all root tips. For seedlings containing only a few ECM root tips, relative abundance was estimated as $1 \%$. Identifications of ectomycorrhizal morphotypes were based on a standard rDNA-internal transcribed spacer (ITS) barcoding procedure (Trocha et al. 2012). Shortly after microscopic examination, total genomic DNA was extracted using a Plant \& Fungi DNA Purification Kit (EURx, Poland). Internal transcribed spacer regions (ITS1-5.8S-ITS2) were amplified via the polymerase 
chain reaction (PCR) using the primers fungal specific ITS1-F and universal ITS4. The PCR reactions were performed in a $10-\mu \mathrm{L}$ volume mixture consisting of $1 \times$ PCR buffer (Novazym, Poland), $1.5 \mathrm{mM} \mathrm{MgCl} 2$ (Novazym, Poland), $0.2 \mathrm{mM}$ of each dNTP (Novazym, Poland), $0.5 \mu \mathrm{M}$ of each primer, $0.02 \mathrm{mg} \mathrm{mL}^{-1}$ BSA (Promega, Madison, WI, USA), $0.25 \mathrm{U}$ of Taq Polymerase (Novazym, Poland), and $5 \mu \mathrm{L}$ of DNA aliquot. Reactions were performed in a thermocycler using the following temperature profiles: $1 \mathrm{~min} 93^{\circ} \mathrm{C}$ (initial denaturation), $1 \min 95^{\circ} \mathrm{C}$ (denaturation), $1 \min 60^{\circ} \mathrm{C}$ (annealing), $2 \min 72{ }^{\circ} \mathrm{C}$ (elongation), $10 \mathrm{~min} 72{ }^{\circ} \mathrm{C}$ (final elongation), and $7{ }^{\circ} \mathrm{C}$ (pause). Steps 2 to 4 were repeated 35 times. PCR products were directly sequenced using primers ITS1 and/or ITS4. DNA sequencing was undertaken using the ABI Prism Big Dye Terminator Sequencing Kit version 3.1 (Applied Biosystems, Foster City, CA, USA). Cycle sequencing was performed using a 2720 Thermal Cycler followed by capillary electrophoresis in an ABI Prism 3130XL Genetic Analyzer (Applied Biosystems, Foster City, CA, USA). The ITS sequences of all morphotypes were compared to sequences in GenBank using the blastn algorithm and then aligned to their best GenBank matches using CodonCode Aligner (http://www.codoncode.com/aligner) at the $97 \%$ identity threshold. The obtained sequences of fungal taxa were deposited in GenBank (accession numbers KP857984 KP857995).

\section{Statistics}

The data were analyzed using three-way analysis of variance (ANOVA) with light, competition, and damage treatments as the main factors and block as a random factor. Prior to ANOVA, homogeneity of variances was tested with Levene's test and normality of distributions with the Shapiro-Wilk test. The main effects ANOVA was applied to test for differences in the mean values of the measured parameters among blocks, damage treatments, competition, and light regimes at $p<0.05$. Then, the full factorial ANOVA was applied (Tables 2, 3, and 4). When the block effect was not significant in the main effects ANOVA, it was excluded from the ANOVA model. The following were the levels in each main factor: light - two levels (low light, high light), competition-two levels (no competition, competition), and damage treatment called "further treatment"-four levels in Fagus and eight levels in Pinus (see Table 1). ANOVA was conducted separately for Fagus and Pinus.

The mean values within the treatments were compared with Tukey's a posteriori test at the significance level $\alpha=0.05$. Prior to ANOVA, the data expressed in percent were transformed using the Bliss function: arcsine $\left((\mathrm{ECM} \text { root tip \%/100) })^{0.5}\right)^{*} 180 / 3.14$ and seedling biomass and leaf $\mathrm{N}$ data were $\log$ transformed prior to
ANOVA. All statistical analyses were conducted with JMP v. 8 (SAS Package, USA).

\section{Results}

\section{ECM root tip abundance and seasonal changes in EMF composition}

Significant differences of ECM root tip abundance (\%) were found among the damage treatments and the control in November (Table 2), when we observed the lowest ECM root tip abundance in the seedlings of treatment 1 (one cotyledon removed, mean $10 \%$ ) and the highest in control seedlings (mean of $29 \%$ ) (Table 3). Competition with grasses showed no effect on ECM root tip abundance (Table 3).

During the season, the mean ECM root tip abundance of Fagus seedlings growing under high light increased from a mean of $0.65 \%$ in July to $36 \%$ in November (Fig. 1). Seedlings growing under high light collected in the final harvest (November) had ca 120 times higher ECM root tip abundance than those growing under low light (Table 3). Ectomycorrhizal fungus species composition in Fagus seedlings collected over a season revealed six EMF taxa in total (Fig. 1). The most frequent EMF species was Cenococcum geophilum, found in the seedlings collected in each harvest, followed by Tuber sp. 1 and Thelephoraceae (Fig. 1).

Pinus seedlings collected in November from both light regimes also showed a strong decrease of ECM root tip abundance under low light (ca $1 \%$ ) compared to those growing under high light ( $83 \%$ ) (Table 4). Pinus seedlings collected in September from the competition treatment showed a strong effect of competition on ectomycorrhizal colonization (Table 2) with a higher ECM root tip abundance in seedlings growing in competition with grasses (ca $3 \%$ ) than those growing alone $(0.5 \%)$ (Table 4$)$.

Ectomycorrhizal colonization in Pinus followed a similar pattern as Fagus and showed an increase over a season starting from the lowest of $0.05 \%$ in July to the highest of $83 \%$ in November (Fig. 2). However, contrary to Fagus seedlings, ectomycorrhizal colonization of Pinus seedlings collected in November did not differ significantly among the damage treatments (Tables 2 and 4).

Ectomycorrhizal species identification revealed three EMF taxa colonizing Pinus roots collected over a season. Root tips of Pinus seedlings were dominated by the ECM fungus Wilcoxina mikolae, while Hebeloma velutipes and Tuber sp. 1 occurred occasionally at low percentages (Fig. 2).

\section{Seedling biomass and leaf nitrogen contents}

Juvenile damage treatment had a significant effect on seedling biomass collected in November (Table 2). The lowest biomass 
Table 2 The results of ANOVAs for ectomycorrhizal tip abundance (ECM tip abundance (\%)), seedling biomass ( $\mathrm{g}$ DW), and leaf $\mathrm{N}$ content (mg N g ${ }^{-1} \mathrm{DW}$ ) of Fagus sylvatica (Fs) and Pinus sylvestris
(Ps) injured mechanically (treatment), growing in low light or high light (light) and in competition with grasses or not (competition)

\begin{tabular}{|c|c|c|c|c|c|c|c|c|c|c|c|c|c|c|c|c|}
\hline \multirow{2}{*}{\multicolumn{2}{|c|}{ Host }} & \multirow[t]{2}{*}{ Trait } & \multicolumn{2}{|c|}{ Treatment } & \multicolumn{2}{|c|}{ Light } & \multicolumn{2}{|c|}{$\begin{array}{l}\text { Treatment } \times \\
\text { light }\end{array}$} & \multicolumn{2}{|c|}{ Competition } & \multicolumn{2}{|c|}{$\begin{array}{l}\text { Treatment } \times \\
\text { competition }\end{array}$} & \multicolumn{2}{|c|}{$\begin{array}{l}\text { Light } \times \\
\text { competition }\end{array}$} & \multicolumn{2}{|c|}{$\begin{array}{l}\text { Treatment } \times \\
\text { light } \times \\
\text { competition }\end{array}$} \\
\hline & & & $d f$ & & $d f$ & $F$ & $d f$ & $F$ & $d f$ & $F$ & $d f$ & $F$ & $d f$ & $F$ & $d f$ & $F$ \\
\hline 1 & Fs & ECM tip abundance (\%) & 3 & $2.91 *$ & 1 & $88.85 * * *$ & 3 & 2.24 n.s. & & & & & & & & \\
\hline 2 & Ps & & 7 & 1.99 n.s. & 1 & $1010 * * *$ & 7 & 1.99 n.s. & & & & & & & & \\
\hline 3 & Ps & & & & & & & & 1 & $24.4 * * *$ & & & & & & \\
\hline 4 & Fs & & & & & & & & 1 & 0.0024 n.s. & & & & & & \\
\hline 5 & Fs & Seedling biomass ( $\mathrm{g}$ ) & 3 & $14.2 * * *$ & 1 & $618 * * *$ & 3 & 2.05 n.s. & 1 & $123^{* * *}$ & 3 & 0.88 n.s. & 1 & $57.1 * * *$ & 3 & 1.00 n.s. \\
\hline 6 & Ps & & 7 & $8.94 * * *$ & 1 & $1415^{* * *}$ & 3 & 1.34 n.s. & & & & & & & & \\
\hline 7 & Ps & & & & & n.a. & & & 1 & $327 * * *$ & & & & & & \\
\hline 8 & Fs & Leaf $\mathrm{N}\left(\mathrm{mg} \mathrm{g}^{-1}\right)$ & 3 & 2.17 n.s. & 1 & $25.6^{* *}$ & 3 & 1.15 n.s. & 1 & $30.2 * * *$ & 3 & 0.81 n.s. & 1 & 0.17 n.s. & 3 & 0.41 n.s. \\
\hline 9 & Ps & & 7 & $3.05 *$ & n.a. & & n.a. & & 1 & $48.2 * * *$ & 7 & 1.88 n.s. & n.a. & & n.a. & \\
\hline
\end{tabular}

Degree of freedom $(d f)$ and $F$ values are given

n.a. not available, n.s. not significant

$* * * p<0.0001 ; * * 0.001>p \geq 0.0001 ; * 0.05>p \geq 0.001$

was for seedlings that had the most foliage removed: five out of eight cotyledons removed (Pinus, treatment no. 5) (Table 4), but Fagus seedlings did not reveal such a pattern (Table 3).

Light affected seedling biomass significantly (Table 2). We found that Fagus seedlings growing under low light had ca 5 times lower biomass (Table 3) than those growing under high light, while Pinus seedlings had an even greater response- biomass of seedlings growing under low light was 22 times lower compared to seedlings growing under high light (Table 4).

Fagus and Pinus mean seedling biomass was 2.7 and 7.5 times lower, respectively, when seedlings grew with grasses compared to seedlings growing without grasses (Tables 3 and 4). Depending on the light regime, the effect of competition was partially reduced as shown for Fagus ECM root tip colonization (Fig. 3a) and seedling biomass (Fig. 3b); however, high light did not improve leaf $\mathrm{N}$ content (Fig. 3c).

Leaf nitrogen content showed no differences among the damage treatments in Fagus, but it did in Pinus (Table 2).
Moreover, significant effects of light conditions and competition were found (Table 2). Fagus seedlings growing in low light had ca 1.2 times more leaf $\mathrm{N}$ than those growing in high light (Table 3). The analysis was not available for Pinus seedlings as there was no sufficient number of replicates from low light (data not shown). Competition with grasses also influenced leaf $\mathrm{N}$ in both tree species (Table 2). For Fagus, seedlings growing in competition revealed higher leaf $\mathrm{N}$ than those growing alone (Fig. 3c; Table 3). However, in Pinus, we observed the opposite trend with higher leaf $\mathrm{N}$ for seedlings growing alone (Table 4).

\section{Discussion}

Trees growing in natural conditions are constantly subjected to a vast number and different types of threats; some of those are mechanical (animal grazing), while others constitute interactions
Table 3 Means ( \pm SE) of ectomycorrhizal (ECM) root tip abundance, seedling biomass, and leaf $\mathrm{N}$ of Fagus sylvatica, growing in low light or high light (light) and in competition with grasses or not (competition); the mean values followed by the same letter are not significantly different in ANOVA (light, competition) or Tukey's a posteriori test (treatment) $(p<0.05)$

\begin{tabular}{|c|c|c|c|c|c|c|c|c|c|c|}
\hline \multirow[t]{2}{*}{ Trait } & \multirow[t]{2}{*}{ Harvest } & \multirow[t]{2}{*}{ Number } & \multicolumn{4}{|l|}{ Treatment } & \multicolumn{2}{|l|}{ Light } & \multicolumn{2}{|l|}{ Competition } \\
\hline & & & 1 & 2 & 3 & 4 & Low & High & No & Yes \\
\hline \multirow{2}{*}{$\begin{array}{l}\text { ECM tip } \\
\quad \text { abundance (\%) }\end{array}$} & November & 64 & $10( \pm 3) b$ & $15( \pm 6) \mathrm{ab}$ & $18( \pm 7) \mathrm{ab}$ & $29( \pm 10) \mathrm{a}$ & $0.3( \pm 0.1) \mathrm{b}$ & $36( \pm 6) \mathrm{a}$ & & \\
\hline & September & 88 & & & & & & & $18( \pm 6.5) \mathrm{a}$ & $13( \pm 6.6) \mathrm{a}$ \\
\hline $\begin{array}{l}\text { Seedling } \\
\quad \text { biomass }(\mathrm{g})\end{array}$ & November & 196 & $1.1( \pm 0.2) \mathrm{ab}$ & $1.0( \pm 0.2) \mathrm{b}$ & $1.4( \pm 0.2) \mathrm{ab}$ & $1.6( \pm 0.3) \mathrm{a}$ & $0.4( \pm 0.02) b$ & $2.1( \pm 0.2) \mathrm{a}$ & $2.2( \pm 0.3) \mathrm{a}$ & $0.8( \pm 0.1) b$ \\
\hline Leaf $N\left(\mathrm{mg} \mathrm{g}^{-1}\right)$ & November & 32 & $22( \pm 1.4) \mathrm{a}$ & $25( \pm 0.9) \mathrm{a}$ & $24( \pm 1.4) \mathrm{a}$ & $25( \pm 1.5) \mathrm{a}$ & $26( \pm 0.8) \mathrm{a}$ & $22( \pm 0.8) \mathrm{b}$ & $22( \pm 0.8) b$ & $26( \pm 0.7) \mathrm{a}$ \\
\hline
\end{tabular}



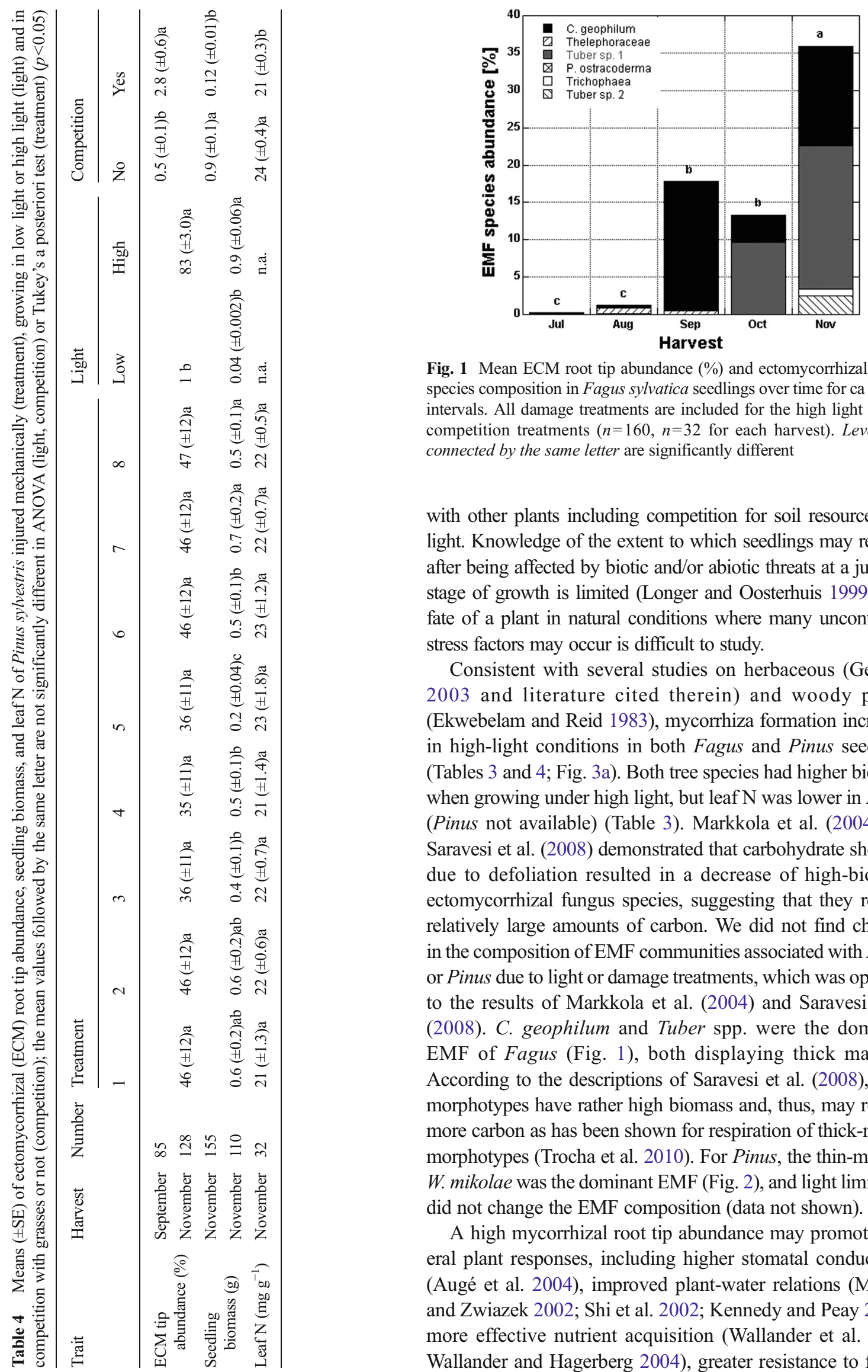

Fig. 1 Mean ECM root tip abundance (\%) and ectomycorrhizal fungal species composition in Fagus sylvatica seedlings over time for ca 30-day intervals. All damage treatments are included for the high light and no competition treatments $(n=160, n=32$ for each harvest). Levels not connected by the same letter are significantly different

with other plants including competition for soil resources and light. Knowledge of the extent to which seedlings may recover after being affected by biotic and/or abiotic threats at a juvenile stage of growth is limited (Longer and Oosterhuis 1999). The fate of a plant in natural conditions where many uncontrolled stress factors may occur is difficult to study.

Consistent with several studies on herbaceous (Gehring 2003 and literature cited therein) and woody plants (Ekwebelam and Reid 1983), mycorrhiza formation increased in high-light conditions in both Fagus and Pinus seedlings (Tables 3 and 4; Fig. 3a). Both tree species had higher biomass when growing under high light, but leaf $\mathrm{N}$ was lower in Fagus (Pinus not available) (Table 3). Markkola et al. (2004) and Saravesi et al. (2008) demonstrated that carbohydrate shortage due to defoliation resulted in a decrease of high-biomass ectomycorrhizal fungus species, suggesting that they require relatively large amounts of carbon. We did not find changes in the composition of EMF communities associated with Fagus or Pinus due to light or damage treatments, which was opposite to the results of Markkola et al. (2004) and Saravesi et al. (2008). C. geophilum and Tuber spp. were the dominant EMF of Fagus (Fig. 1), both displaying thick mantles. According to the descriptions of Saravesi et al. (2008), these morphotypes have rather high biomass and, thus, may require more carbon as has been shown for respiration of thick-mantle morphotypes (Trocha et al. 2010). For Pinus, the thin-mantled W. mikolae was the dominant EMF (Fig. 2), and light limitation did not change the EMF composition (data not shown).

A high mycorrhizal root tip abundance may promote several plant responses, including higher stomatal conductance (Augé et al. 2004), improved plant-water relations (Muhsin and Zwiazek 2002; Shi et al. 2002; Kennedy and Peay 2007), more effective nutrient acquisition (Wallander et al. 1994; Wallander and Hagerberg 2004), greater resistance to fungal 


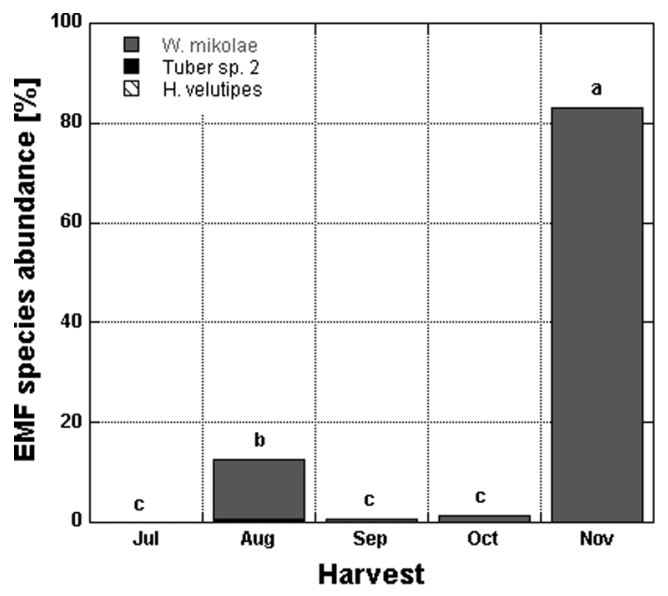

Fig. 2 Mean ECM root tip abundance (\%) and ectomycorrhizal fungal species composition in Pinus sylvestris seedlings over time for ca 30-day intervals. All damage treatments are included for the high light and no competition treatments $(n=319, n=63-64$ for each harvest). Levels not connected by the same letter are significantly different

pathogens (Branzanti et al. 1999), and higher photosynthetic activity (Dosskey et al. 1990). Growing in a well-mixed fungal community (pot substrate containing a forest soil mix), seedlings were subjected to both beneficial and less beneficial EMF species in terms of carbon costs to the hosts (Bever et al. 2009). EMF communities did not, however, respond to light or damage treatments. Plant biomass and ECM root tip abundance of either Pinus or Fagus were affected negatively by low light, indicating light as a factor of high importance for plant and ECM fungi niche partitioning (Brearley et al. 2007). The dominance of Ascomycota colonizing the roots of Fagus and Pinus seedlings in our experiment is difficult to explain: it could result from disturbed (mixed) soil or carbon demands of the fungi/amounts of carbon allocated to roots in very young seedlings. It has been shown that the species of Ascomycota (mostly Wilcoxina sp.) dominated in the seedlings of conifer tree species grown under nursery conditions (Rudawska et al. 2006; Trocha et al. 2006; Leski et al. 2008). However, Basidiomycota dominated in other tree seedlings, including conifers, growing under similar nursery conditions (Leski et al. 2010; Menkis and Vasaitis 2011). We think that this issue needs more attention in future research.

Defoliation of a very young seedling may trigger different compensatory mechanisms, including an increase in photosynthetic activity in the remaining leaves (Mabry and Wayne 1997), foliage increase (Khan et al. 2002), and increase in mineral nutrient uptake (Ruess 1984), which, in turn, may cause better plant growth (McNaughton 1983). However, numerous papers report a negative effect of defoliation on seedling survival (e.g., von Schütt 1973; Myers 1981; Wilkinson and Nielsen 1995; Muro et al. 1998; Li and Ma 2003). Our results support the latter finding: the biomass of 6-month-old Pinus and Fagus seedlings was influenced negatively by juvenile damage (Tables 3 and 4; Fig. 3b). The most significant
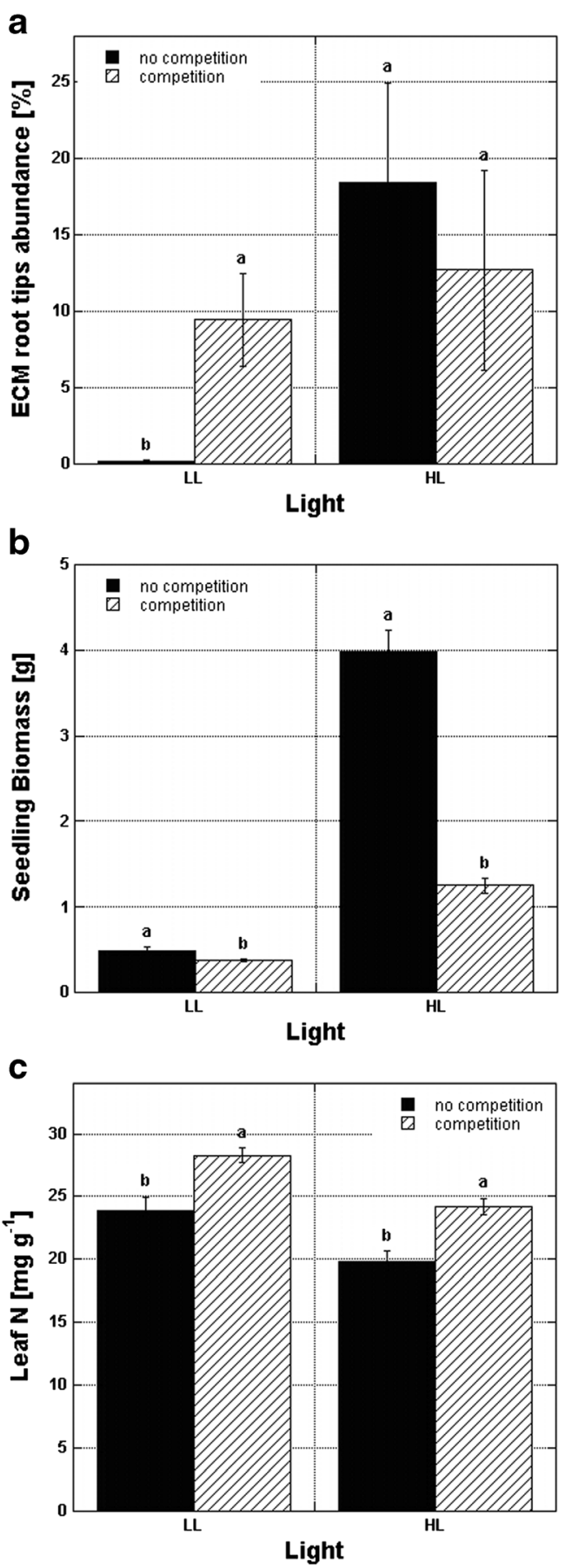

Fig. 3 Effect of competition within light regimes on ECM root tip abundance (a), seedling biomass (b), and leaf N (c) of Fagus sylvatica; $L L$ low light, $H L$ high light; levels not connected by the same letter are significantly different between competition treatments within each light regime; $n=88$ (a), $n=196$ (b), and $n=32$ (c)

response that resulted in the lowest mean ECM root tip abundance and biomass was caused by the most intensive damage: removing five (out of eight) cotyledons in Pinus (Table 4), suggesting that photosynthesis shortage is a determining factor in plant functioning. However, when ECM root tip abundances among damage treatments were analyzed separately 
under the light regimes (not shown), organ loss did not affect ectomycorrhizal colonization, suggesting that light is a predominant factor influencing plant physiology.

Interspecific competition is one of the most important forces shaping the diversity of plant communities and total aboveground plant biomass (Del-Val and Crawley 2005). The effect of competition on ECM root tip abundance was different between the two tree species studied (Tables 3 and 4). Competition with arbuscular-mycorrhizal shrubs decreased both biomass and ectomycorrhizal colonization in Pinus edulis, while in our research, we noticed that competition promoted ECM root tip colonization in Pinus seedlings, but not in Fagus, and simultaneously decreased their biomass (Tables 3 and 4). That is striking, as many researchers have observed that competition negatively impacted ECM root tip colonization in many ecosystems (McHugh and Gehring 2006 and literature cited). Light availability promoted ectomycorrhizal colonization (Fig. 3a) and seedling biomass in the "no competition" treatment (Fig. 3b), again suggesting light's predominant role in plant functioning. However, Cheng and Bledsoe (2004) found a negative effect of grass both underground and aboveground that reduced Quercus seedling growth and soil nitrogen availability. The impact of grasses could be both direct (competing for soil resources with other plants) and indirect - grasses may change the microclimate around seedlings in a way that hinders growth (Ball et al. 2002).

We clearly showed that light availability is the main factor affecting seedling growth and ectomycorrhizal root tip colonization in our study. High light (50\% of full irradiance) compensated to some extent for the negative effects of organ loss and competition with grasses on ectomycorrhizal colonization and growth of $P$. sylvestris and $F$. sylvatica seedlings.

\begin{abstract}
Acknowledgments We would like to thank Roma Żytkowiak for her help in chemical analyses, Dr. Lee E. Frelich for language correction, and the Jarocin Forest District for seed delivery. We are cordially thankful to two anonymous reviewers for their helpful comments. The study was supported by grant no. N305 009 31/0371 financed by the Polish Ministry of Science and Higher Education.
\end{abstract}

Open Access This article is distributed under the terms of the Creative Commons Attribution 4.0 International License (http:// creativecommons.org/licenses/by/4.0/), which permits unrestricted use, distribution, and reproduction in any medium, provided you give appropriate credit to the original author(s) and the source, provide a link to the Creative Commons license, and indicate if changes were made.

\section{References}

Archer S, Detling JK (1984) The effect of defoliation and competition on re-growth of tillers of two North American mixed-grass prairie graminoids. Oikos 43:351-357
Augé RM, Moore JL, Sylvia DM, Cho K (2004) Mycorrhizal promotion of host stomatal conductance in relation to irradiance and temperature. Mycorrhiza 14:85-92

Avila-Sakar G, Stephenson AG (2006) Effects of the spatial pattern of leaf damage on growth and reproduction: whole plants. Int J Plant Sci 167:1021-1028

Ball MC, Egerton JJG, Lutze JL, Gutschick VP, Cunningham RB (2002) Mechanisms of competition: thermal inhibition of tree seedling growth by grass. Oecologia 133:120-130

Baxter JW, Dighton J (2005) Phosphorus source alters host plant response to ectomycorrhizal diversity. Mycorrhiza 15:513-523

Bever JD, Richardson SC, Lawrence BM, Holmes J, Watson M (2009) Preferential allocation to beneficial symbiont with spatial structure maintains mycorrhizal mutualism. Ecol Lett 12:13-21

Bloom AJ, Chapin FS III, Mooney HA (1985) Resource limitation in plants - an economic analogy. Annu Rev Ecol Syst 16:363-392

Branzanti MB, Elisabetta Rocca E, Annamaria Pisi A (1999) Effect of ectomycorrhizal fungi on chestnut ink disease. Mycorrhiza 9:103109

Brearley FQ, Scholes JD, Press MC, Palfner G (2007) How does light and phosphorus fertilisation affect the growth and ectomycorrhizal community of two contrasting dipterocarp species? Plant Ecol 192:237249

Bryla DR, Eissenstat DM (2005) Respiratory costs of mycorrhizal associations. In: Lambers H, Ribas-Carbo M (eds) Plant respiration. Springer, Dordrecht, pp 207-224

Bücking H, Heyser W (2003) Uptake and transfer of nutrients in ectomycorrhizal associations: interactions between photosynthesis and phosphate nutrition. Mycorrhiza 13:59-68

Chapin FS III, Slack M (1979) Effect of defoliation upon root growth, phosphate absorption and respiration in nutrient-limited tundra graminoids. Oecologia 42:67-79

Cheng X, Bledsoe CS (2004) Competition for inorganic and organic $\mathrm{N}$ by blue oak (Quercus douglasii) seedlings, an annual grass, and soil microorganisms in a pot study. Soil Biol Biochem 36:135-144

Clark EC (1956) The Great Basin tent caterpillar in relation to bitterbush in California. Calif Fish Game 42:131-142

Davies FT Jr, Svenson SE, Cole C, Phavaphutanon L, Duray SA, OlaldePortugal V, Meier CE, Bo SH (1996) Non-nutritional stress acclimation of mycorrhizal woody plants exposed to drought. Tree Physiol 16:985-993

De Chantal M, Leinonen K, Kuuluvainen T, Cescatti A (2003) Early response of Pinus sylvestris and Picea abies seedlings to an experimental canopy gap in a boreal spruce forest. For Ecol Manag 176: 321-336

Del-Val E, Crawley MJ (2005) What limits herb biomass in grasslands: competition or herbivory? Oecologia 142(2):202-211

Dosskey GM, Linderman RG, Boersma L (1990) Carbon-sink stimulation of photosynthesis in Douglas fir seedlings by some ectomycorrhizas. New Phytol 115:269-274

Ekwebelam SA, Reid CPP (1983) Effect of light, nitrogen fertilization, and mycorrhizal fungi on growth and photosynthesis of lodgepole pine seedlings. Can J For Res 13:1099-1106

Evans PS (1972) Root growth of Lolium perenne L. III. Investigation of the mechanisms of defoliation induced suppression of elongation. $\mathrm{N}$ Z J Agric Res 15:347-355

Facelli E, Facelli JM, Smith SE, McLaughlin (1999) Interactive effects of arbuscular mycorrhizal symbiosis, intraspecific competition and resource availability on Trifolium subterraneum cv. Mt. Barker. New Phytol 141:535-547

Gehring CA (2003) Growth responses to arbuscular mycorrhizae by rain forest seedlings vary with light intensity and tree species. Plant Ecol 167:127-139

Hampp R, Wiese J, Mikolajewski S, Nehls U (1999) Biochemical and molecular aspects of $\mathrm{C} / \mathrm{N}$ interaction in ectomycorrhizal plants: an update. Plant Soil 215:103-113 
Hartnett DC, Hetrick BAD, Wilson GWT, Gibson DJ (1993) Mycorrhizal influence on intra- and interspecific neighbor interactions among cooccurring prairie grasses. J Ecol 81:787-795

Hobbie EA (2006) Carbon allocation to ectomycorrhizal fungi correlates with belowground allocation in culture studies. Ecology 87:563569

Kennedy PG, Peay KG (2007) Different soil moisture conditions change the outcome of the ectomycorrhizal symbiosis between Rhizopogon species and Pinus muricata. Plant Soil 291:155-165

Khan NA, Khan M, Ansari HR, Samiullah (2002) Auxin and defoliation effects on photosynthesis and ethylene evolution in mustard. Sci Hortic 96:43-51

Kitajima K (1994) Relative importance of photosynthetic traits and allocation patterns as correlates of seedling shade tolerance of 13 tropical trees. Oecologia 98:419-428

Koide RT (1991) Density-dependent response to mycorrhizal infection in Abutilon theophrasti Medic. Oecologia 85:389-395

Kosola KR, Dickmann DI, Paul EA, Parry D (2001) Repeated insect defoliation effects on growth, nitrogen acquisition, carbohydrates, and root demography of poplars. Oecologia 129:65-74

Kuikka K, Härmä E, Markkola A, Rautio P, Saikkonen K, AhonenJonnarth U, Finlay R, Tuomi J (2003) Severe defoliation of Scots pine reduces reproductive investments by ectomycorrhizal symbionts. Ecology 84:2051-2061

Lambers H, Poorter H, van Vuuren MMI (1998) Inherent variation in plant growth. Physiological mechanisms and ecological consequences. Backhuys, Leiden

Lerat S, Lapointe L, Gutjahr S, Piché Y, Vierheilig H (2003) Carbon partitioning in a split-root system of arbuscular mycorrhizal plants is fungal and plant species dependent. New Phytol 157:589-595

Leski T, Rudawska M, Aučina A (2008) The ectomycorrhizal status of European larch (Larix decidua Mill.) seedlings from bare-root forest nurseries. For Ecol Manag 256:2136-2144

Leski T, Pietras M, Rudawska M (2010) Ectomycorrhizal fungal communities of pedunculate and sessile oak seedlings from bare-root forest nurseries. Mycorrhiza 20:179-190

Li Q, Ma K (2003) Factors affecting establishment of Quercus liaotungensis Koidz. under mature mixed oak forest overstory and in shrubland. For Ecol Manag 176:133-146

Lilleskov EA, Fahey TJ, Horton TR, Lovett GM (2002) Belowground ectomycorrhizal fungal community change over a nitrogen deposition gradient in Alaska. Ecology 83:104-115

Lincoln DE, Mooney HA (1984) Herbivory on Diplacus aurantiacus shrubs in sun and shade. Oecologia 64:173-176

Little CHA, Lavigne MB, Ostaff DP (2003) Impact of old foliage removal, simulating defoliation by the balsam fir sawfly, on balsam fir tree growth and photosynthesis of current-year shoots. For Ecol Manag 186:261-269

Longer DE, Oosterhuis DM (1999) Cotton regrowth and recovery from early season leaf loss. Environ Exp Bot 41:67-73

Mabry CM, Wayne PW (1997) Defoliation of the annual herb Abutilon theophrasti: mechanisms underlying reproductive compensation. Oecologia 111:225-232

Markkola A, Kuikka K, Rautio P, Härmä E, Riotto M, Tuomi J (2004) Defoliation increases carbon limitation in ectomycorrhizal symbiosis of Betula pubescens. Oecologia 140:234-240

Maschinski J, Whitham TG (1989) The continuum of plant responses to herbivory: the influence of plant association, nutrient availability and timing. Am Nat 134:1-19

McHugh T, Gehring CA (2006) Below-ground interactions with arbuscular mycorrhizal shrubs decrease the performance of pinyon pine and the abundance of its ectomycorrhizas. New Phytol 171: $171-178$

McNaughton SJ (1983) Compensatory plant growth as a response to herbivory. Oikos 40:329-336
Menkis A, Vasaitis R (2011) Fungi in roots of nursery grown Pinus sylvestris: ectomycorrhizal colonisation, genetic diversity and spatial distribution. Microb Ecol 61:52-63

Minotta G, Pinzauti S (1996) Effects of light and soil fertility on growth, leaf chlorophyll content and nutrient use efficiency of beech (Fagus syluatica L.) seedlings. For Ecol Manag 86:61-71

Muhsin TM, Zwiazek JJ (2002) Ectomycorrhizas increase apoplastic water transport and root hydraulic conductivity in Ulmus americana seedlings. New Phytol 153:153-158

Muro J, Irigoyen I, Lamsfus C (1998) Effect of defoliation on onion crop yield. Sci Hortic 77:1-10

Myers JH (1981) Interactions between western tent caterpillars and wild rose: a test of some general plant herbivore hypotheses. J Anim Ecol 50:11-25

Nehls U, Göhringer F, Wittulsky S, Dietz S (2010) Fungal carbohydrate support in the ectomycorrhizal symbiosis: a review. Plant Biol 12: 292-301

Oleksyn J, Karolewski P, Giertych MJ, Żytkowiak R, Reich PB, Tjoelker MG (1998) Primary and secondary host plants differ in leaf-level photosynthetic response to herbivory: evidence from Alnus and Betula grazed by the alder beetle, Agelastica alni. New Phytol 140:239-249

Pearcy RW, Valladares F, Wright SJ, de Paulis EL (2004) A functional analysis of the crown architecture of tropical forest Psychotria species: do species vary in light capture efficiency and consequently in carbon gain and growth? Oecologia 139:163-177

Pedersen CT, Sylvia DM, Shilling DG (1999) Pisolithus arhizus ectomycorrhiza affects plant competition for phosphorus between Pinus elliottii and Panicum chamaelonche. Mycorrhiza 9:199-204

Pena R, Offermann C, Simon J, Naumann PS, Geßler A, Holst J, Dannenmann M, Mayer H, Kögel-Knabner I, Rennenberg H, Polle A (2010) Girdling affects ectomycorrhizal fungal (EMF) diversity and reveals functional differences in EMF community composition in a beech forest. Appl Environ Microbiol 76:1831-1841

Perez-Moreno J, Read DJ (2000) Mobilization and transfer of nutrients from litter to tree seedlings via the vegetative mycelium of ectomycorrhizal plants. New Phytol 145:301-309

Rudawska M, Leski T, Trocha LK, Gornowicz R (2006) Ectomycorrhizal status of Norway spruce seedlings from bare-root forest nurseries. For Ecol Manag 236:375-384

Ruess RW (1984) Nutrient movement and grazing: experimental effects of clipping and nitrogen source on nutrient uptake in Kyllinga nervosa. Oikos 43:183-188

Saikkonen K, Ahonen-Jonnarth U, Markkola A, Helander M, Tuomi J, Roitto M, Ranta H (1999) Defoliation and mycorrhizal symbiosis: a functional balance between carbon sources and below-ground sinks. Ecol Lett 2:19-26

Saravesi K, Markkola A, Rautio P, Roitto M, Juha Tuomi J (2008) Defoliation causes parallel temporal responses in a host tree and its fungal symbionts. Oecologia 156:117-123

Shi L, Guttenberger M, Kottke I, Hampp R (2002) The effect of drought on mycorrhizas of beech (Fagus sylvatica L.): changes in community structure, and the content of carbohydrates and nitrogen storage bodies of the fungi. Mycorrhiza 12:303-311

Tester M, Smith SE, Smith FA, Walker NA (1986) Effects of photon irradiance on the growth of shoots and roots, on the rate of initiation of mycorrhizal infection and on the growth of infection units in Trifolium subterraneum L. New Phytol 103:375-390

Trocha LK, Rudawska M, Leski T, Dabert M (2006) Genetic diversity of naturally established ectomycorrhizal fungi on Norway spruce seedlings under nursery conditions. Microb Ecol 52:418-425

Trocha LK, Mucha J, Eissenstat DM, Reich PB, Oleksyn J (2010) Ectomycorrhizal identity determines respiration and concentrations of nitrogen and nonstructural carbohydrates in root tips: a test using Pinus sylvestris and Quercus robur saplings. Tree Physiol 30:648654 
Trocha LK, Kałucka I, Stasińska M, Nowak W, Dabert M, Leski T, Rudawska M, Oleksyn J (2012) Ectomycorrhizal fungal communities of native and non-native Pinus and Quercus species in a common garden of 35-year-old trees. Mycorrhiza 22:121-134

von Schütt P (1973) Ein Hinweis für Zusammenhänge zwischen Cotyledonenzahl und Wuchsleistung bei Nadelholz-Sämlingen. Forstwissenschaftliches Centralblatt 92:19-24

Wallander H, Hagerberg D (2004) Do ectomycorrhizal fungi have a significant role in weathering of minerals in forest soil? Symbiosis 37: 249-257
Wallander H, Nylund J-E, Sundberg B (1994) The influence of IAA, carbohydrate and mineral concentration in host tissue on ectomycorrhizal development on Pinus sylvestris L. in relation to nutrient supply. New Phytol 127:521-528

Welander NT, Ottosson B (1998) The influence of shading on growth and morphology in seedlings of Quercus robur L. and Fagus sylvatica L. For Ecol Manag 107:117-126

Wilkinson GR, Nielsen WA (1995) Implication of early browsing damage on the long term productivity of eucalypt forest. For Ecol Manag 74: $117-124$ 